\title{
Progesterone signaling mechanisms in brain and behavior
}

\author{
Shaila K. Mani ${ }^{1,2}{ }^{*}$ and Mario G. Oyola ${ }^{1}$ \\ Center on Addiction, Learning and Memory, Department of Neuroscience, Baylor College of Medicine, Houston, TX, USA \\ 2 Department of Molecular and Cellular Biology, Baylor College of Medicine, Houston, TX, USA
}

\section{Edited by:}

Kazuyoshi Tsutsui, Waseda University, Japan

\section{Reviewed by:}

Suguru Kawato, University of Tokyo, Japan

Nobuhiro Harada, Fujita Health

University School of Medicine, Japan

*Correspondence:

Shaila K. Mani, Department of Molecular and Cellular Biology, Baylor College of Medicine, One Baylor Plaza, Houston, TX 77030, USA.

e-mail:smani@bcm.edu
Steroid hormone, progesterone, modulates neuroendocrine functions in the central nervous system resulting in alterations in physiology and behavior. These neuronal effects are mediated primarily by intracellular progestin receptors (PRs) in the steroid-sensitive neurons, resulting in transcription-dependent genomic actions (classical mechanism). In addition to progesterone, intracellular PRs can also be activated in a "ligand-independent" manner by neurotransmitters, peptide growth factors, cyclic nucleotides, and neurosteroids. Recent studies indicate that rapid, non-classical progesterone actions involving cytoplasmic kinase signaling and/or extranuclear PRs can result in both transcriptionindependent and transcription-dependent actions. Cross-talk between extranuclear and classical intracellular signaling pathways promotes progesterone-dependent behavior in mammals. This review focuses on the mechanisms by which progesterone-initiated signaling mechanisms converge with PRs in the brain to modulate reproductive behavior in female rodents.

Keywords: progesterone, progestin receptors, dopamine, non-classical, signaling, cross-talk

\section{INTRODUCTION}

Ovarian steroid hormones, estradiol $\left(\mathrm{E}_{2}\right)$ and progesterone $(\mathrm{P})$ regulate cellular functions in the central nervous system resulting in alterations in reproductive physiology and behaviors in various species (Young, 1969; Pfaff, 1980; Blaustein and Olster, 1989; Meisel et al., 1990; Pfaff et al., 1994; Blaustein and Mani, 2007; Mani and Portillo, 2010). In addition to reproduction, $\mathrm{P}$ plays a role on other biological functions including aggression, maternal behavior, learning and memory, mood, and sexual differentiation (Fraile et al., 1987; Meisel et al., 1990; Flood et al., 1992; Vallee et al., 1997; Wagner et al., 1998; Numan et al., 1999; Bloch et al., 2000; Wagner, 2006; Dreher et al., 2007). While P-initiated mechanisms contributing to these physiological effects are actively being investigated, a wide body of literature exists on $\mathrm{P}$ action in reproductive behavior in female rodents. Reproductive behavior can be manipulated in a predictable fashion by sequential treatment of $\mathrm{E}_{2}$ and $\mathrm{P}$ to an ovariectomized female rodent (Young, 1969; Pfaff, 1980; Feder, 1984). This behavior can be measured with a high degree of validity and reliability, and has remained the model of choice for investigations of mechanisms of $\mathrm{P}$ action in the brain.

\section{NEURAL PROGESTIN RECEPTORS AND CLASSICAL MECHANISM OF PROGESTERONE ACTION}

Although diverse cellular mechanisms have been ascribed to the $\mathrm{P}$ action in the brain, the primary mechanism involves its interaction with $\mathrm{E}_{2}$-induced, intracellular progestin receptors (PRs), which function as transcriptional factors, regulating the expression of genes and genomic neural networks to initiate, and/or sustain physiological response (Blaustein and Olster, 1989; Pfaff et al., 1994). PRs undergo significant conformational change upon binding by progesterone, leading to their nuclear translocation, dimerization, and DNA binding (Tsai and O'Malley, 1994;
O'Malley et al., 1995; Mani and O'Malley, 2002). When bound to DNA, PRs interact with basal transcriptional machinery, assisted by coactivator molecules to initiate chromatin remodeling (Horwitz et al., 1996; Katzenellenbogen et al., 1996; McKenna et al., 1999). Phosphorylation of the coactivators also plays a crucial role in the activation of steroid receptors (Rowan et al., 2000b).

This classical, genomic $\mathrm{P}$ action mediated by PRs has a delayed onset and is a protracted process. Temporal and functional correlation studies support this delayed action paradigm and suggest that PRs function as transcriptional mediators to regulate target gene transcription and affect the neural networks involved in the control of female reproductive behavior (Pfaff et al., 1994, 2002). The time course of activation and termination of sexual behavior parallels $\mathrm{E}_{2}$-induced increase and decline in PRs in the ventrolateral region of the ventromedial hypothalamus $(\mathrm{VMH})$ and the preoptic area (POA) of the brain (Dempsey et al., 1936; Blaustein and Feder, 1980; Parsons et al., 1980; Rubin and Barfield, 1983; Brown et al., 1987). Studies using PR antagonists, protein and RNA synthesis inhibitors, antisense oligonucleotides to $\mathrm{PR}$, and mutant mice with targeted deletion of PR gene have highlighted the involvement of PR-mediated genomic mechanism in the mediation of P-facilitated reproductive behavior (Whalen, 1974; Rainbow et al., 1982; Meisel and Pfaff, 1984, 1985; Pollio et al., 1993; Mani et al., 1994c, 1996; Ogawa et al., 1994).

A role for steroid receptor coactivators (SRCs) in PR-mediated female reproductive behaviors has also been reported. Using antisense oligonucleotides for SRC-1 and cAMP response element binding protein (CBP), Molenda et al. (2002) and MolendaFigueira et al. (2006) demonstrated the requirement of both the coactivators in P-facilitation of female reproductive behavior. Apostolakis et al. (2002) have demonstrated a role for SRC-2 in the PR-mediated female reproductive behavior. Interestingly, a strong 
association between PRs and coactivators, SRC-1 and SRC-2, has been demonstrated using pull down assays (Molenda-Figueira et al., 2008; Yore et al., 2010). In addition to the hypothalamus, coactivators are also expressed in various regions of the brain, including the hippocampus, amygdala, and dentate gyrus (Ogawa et al., 2001; Yore et al., 2010).

Multiple PR isoforms have been reported in various $\mathrm{P}$-sensitive tissues and are a result of transcription from different translational sites from a single PR gene (Conneely et al., 1989; Kastner et al., 1990; Kraus et al., 1993). Two major isoforms, PR-A and PR-B, have been reported in the rat brain. PR-B is a full-length protein consisting of 933 amino acids, while PR-A lacks 165 amino acids in the $\mathrm{N}$-terminus. The isoforms have differential expression patterns and are regulated in a region-specific manner in the brain (Mani et al., 2006; Mani, 2008). Studies in mice in which PR-A and PR-B have been mutated have established a critical role for PR-A isoform in the P-facilitation of female reproductive behavior in female mice (Mani et al., 2006). The studies also suggested that PR-A isoform was necessary, but not sufficient, to mediate the full magnitude of the behavioral response in the absence of PR-B isoform (Mani et al., 2006). Interestingly, using antisense oligonucleotides to PR isoforms, Guerra-Araiza et al. (2009) report that PR-B was sufficient for P-facilitation of lordosis response in female rats. Furthermore, antisense oligonucleotides to PR-B or PR-A + PR-B combination inhibited not only P, but also its ringA reduced metabolite $5 \alpha$-pregnan-3, 20-dione ( $5 \alpha$-DHP)-, and $5 \beta$, $3 \beta$-pregnan-20-one ( $5 \beta, 3 \beta$-Pgl)-facilitated lordosis in $\mathrm{E}^{2}$-primed female rats (Guerra-Araiza et al., 2009). These reports suggest the critical importance of PR in general, and PR-B isoform in specific, in P metabolite-facilitated female receptive behavior in rats.

Progesterone also plays a role in the termination of sexual behavior during estrous cycle (Sodersten and Hansen, 1977, 1979; Sodersten and Eneroth, 1981) and pregnancy (Baum et al., 1979). Rats, hamsters, guinea pigs, and mice, become refractory to reproductive behavior, upon further stimulation by the administration of $\mathrm{P}$ or by $\mathrm{E}_{2}$ and $\mathrm{P}$ (Dempsey et al., 1936; Goy et al., 1966; Carter et al., 1976; Blaustein and Wade, 1977; Morin, 1977; Baum et al., 1979; Fadem et al., 1979; Blaustein, 1982a; Fabre-Nys and Gelez, 2007). This effect is generally referred to as postestrousrefractoriness (Morin, 1977) or sequential inhibition (Blaustein and Wade, 1977; Blaustein and Feder, 1979b) of P, is believed to limit the duration of behavioral estrus and is thought to occur due to P-dependent down-regulation of PRs (Blaustein and Wade, 1977; Blaustein and Feder, 1979b; Blaustein, 1982a). The hyposensitivity to $\mathrm{P}$ during this period could be attributable to the inadequate accumulation of occupied nuclear PRs, in response to P (Blaustein and Feder, 1979a, 1980). Administration of high pharmacological dose of $\mathrm{P}$, not only re-instated $\mathrm{P}$ responsiveness, but also resulted in an increase in P-occupied hypothalamic PRs (Blaustein, 1982b). Furthermore, pharmacological agents that prevent degradation of the PRs by inhibiting $26 \mathrm{~S}$ proteosome activity, not only stabilized the concentration of PRs within the hypothalamus and POA, but also prevented the P-induced refractoriness in female rats, confirming that the behavioral refractoriness is causally related to the down-regulation of PRs (Gonzalez-Flores et al., 2004, 2008; Etgen et al., 2006; Gomez-Camarillo et al., 2011).
NON-CLASSICAL MECHANISMS OF PROGESTERONE ACTION

While genomic effects characterized by a delayed onset have traditionally been assumed to be the primary pathway for progesterone action in the brain, recent studies suggest the involvement of "non-classical" mechanisms of progesterone action. These nonclassical short-latency effects of progesterone widely affect cell functioning, through modulation of putative cell surface receptors, ion channels, and mechanisms coupled to cytoplasmic second messenger signaling cascades, independent of gene transcription (Schumacher et al., 1999; Beyer et al., 2003; Leonhardt et al., 2003; Boonyaratanakornkit et al., 2008). Extranuclear rapid and transient activation has been demonstrated to involve mitogenactivated protein kinase (MAPK), independent of PR transcriptional activity in mammalian cells in vitro (Migliaccio et al., 1998; Boonyaratanakornkit et al., 2001). P signaling mediated by G protein $\beta \gamma$ subunits have been shown to activate the downstream MAPK cascade during meiotic progression in Xenopus oocytes, demonstrating a biologically important role for $\mathrm{G}$ proteins in nonclassical signaling (Blackmore, 1998; Ferrell and Machleder, 1998; Ferrell, 1999; Lutz et al., 2000). Rapid effects of steroid hormones have also been demonstrated on the release of LHRH (Ramirez et al., 1990), dopamine and acetylcholine (Meiri, 1986), release of excitatory amino acids (Smith et al., 1987), and changes in neuronal activity (Kelly et al., 1977a,b; Havens and Rose, 1988). In addition to $\mathrm{P}$, several of its ring-A reduced metabolites have been shown to facilitate lordosis response in ovariectomized, $\mathrm{E}_{2}$-primed female rats via activation of MAPK pathway (Gonzalez-Flores et al., 2004, 2009). Others and we have reported the involvement of at least four extranuclear kinase systems, protein kinase A (PKA), protein kinase $\mathrm{C}(\mathrm{PKC})$, calcium and calmodulin kinase II (CaMKII), and protein kinase $\mathrm{G}(\mathrm{PKG})$ in the rapid P effects in the VMH and POA of the female rat (Beyer and Gonzalez-Mariscal, 1986; Petitti and Etgen, 1989, 1990; Schumacher et al., 1990; Kow et al., 1994; Chu and Etgen, 1997; Chu et al., 1999; Gonzalez-Flores et al., 2006; Balasubramanian et al., 2008a,b). Since the initiation of these non-classical effects occurs rapidly (in seconds or minutes) and is triggered at the membrane surface, the classical model of nuclear PR-mediation is inadequate to account for these effects.

\section{MEMBRANE RECEPTORS UNRELATED TO CLASSICAL PRS}

Recent evidence suggest the involvement of two types of novel membrane proteins unrelated to classical PRs, progesterone membrane receptor component 1 (PGMRC1) and progesterone membrane receptors (mPRs), in P signaling in several reproductive tissues and in the brain. PGMRC1, unrelated to the classical PR, was originally isolated from porcine liver membranes (Falkenstein et al., 1996, 1998; Meyer et al., 1996; Gerdes et al., 1998). Expression of 25-Dx, a homologous protein in rat (Selmin et al., 1996) was shown to be upregulated by $E_{2}$ and down regulated by $P$ in the VMH of female rat (Krebs et al., 2000). The functional role of this protein and its downstream signaling pathway remains to be established.

The mPRs ( $\mathrm{Mw} \sim 40 \mathrm{kDa}$ ), initially discovered in teleost ovaries, are $\mathrm{G}$ protein coupled receptors (GPCRs) that belong to the seven-transmembrane adiponectin $\mathrm{Q}$ receptor (PAQR) family, and comprise of at least three subtypes, $\alpha, \beta$, and $\gamma$.The mPRs localize to the plasma membrane, bind progesterone with high affinity 
$\left(K_{\mathrm{d}} \sim 5 \mathrm{nM}\right)$ and are involved in progesterone-mediated induction of sea trout meiotic maturation (Zhu et al., 2003a,b) and sperm motility (Tubbs and Thomas, 2008). mPRs are directly coupled to $G$ proteins and activate pertussis-sensitive inhibitory proteins $\left(\mathrm{G}_{\mathrm{i} / \mathrm{o}}\right)$, to down-regulate adenylyl cyclase activity (Thomas et al., 2007). Human analogs of the mPRs, when expressed in human breast cancer cells, which lack classical PRs, mediate a rapid and transient P-mediated activation of MAPK, and inhibition of cAMP production. Endogenous $\mathrm{mPR} \alpha$ and $\mathrm{mPR} \beta$ in human myometrium was also shown to mediate inhibition of cAMP and to increase myosin light chain phosphorylation resulting in myometrial contraction (Karteris et al., 2006). Progestin upregulation of $\mathrm{mPR}$ has been reported to potentiate classical PR-B transactivation by a mechanism involving $G_{i}$ proteins and a reduction in SRC-2 coactivator levels, suggesting a cross-talk between the membrane and nuclear PRs (Karteris et al., 2006). Sleiter et al. (2009) have reported the presence of $\mathrm{mPR} \alpha$ and $\mathrm{mPR} \beta$ message in the medial basal hypothalamus and their involvement in the negative feedback effects of $\mathrm{P}$ on gonadotropin releasing hormone $(\mathrm{GnRH})$ secretion. Using the PR knockout mice and GT1-7 cells, the authors demonstrated that these mPR-mediated $P$ effects inhibit cAMP accumulation (via $G_{i}$ ) and are independent of the classical nuclear PR isoforms, PR-A and PR-B.

\section{LIGAND-INDEPENDENT ACTIVATION OF PRs}

Studies in the past decades have demonstrated that PRs can be activated by factors other than $\mathrm{P}$ (ligand-independent activation). A number of second messenger molecules, including $3^{\prime}-5^{\prime}$ cyclic adenosine monophosphate (cAMP), $3^{\prime}-5^{\prime}$-cyclic guanosine monophosphate (cGMP), nitric oxide (NO), and neurotransmitters have been shown to substitute for $\mathrm{P}$ in the facilitation of reproductive behavior in female rats (Mani et al., 1994a,b; Chu and Etgen, 1997; Gonzalez-Flores et al., 2009). Inhibition of MAPK signaling pathway results in reduction of $\mathrm{P}$, dibutyryl-cAMP $(\mathrm{db}$ cAMP)-, prostaglandin $\mathrm{E}_{2}\left(\mathrm{PGE}_{2}\right)^{-}$, or $\mathrm{GnRH}$-facilitated female reproductive behavior in rats (Gonzalez-Flores et al., 2008). These studies suggest the involvement of multiple signal transduction pathways in female reproductive behavior.

Over the past several years, studies from our laboratory have demonstrated that in addition to $\mathrm{P}$, the neurotransmitter dopamine (DA) can activate neural PRs to facilitate reproductive behavior (Mani et al., 1994a,b,c). Using PR antagonists, antisense oligonucleotides and null mutants for PRs, we demonstrated a critical requirement of classical PRs as transcriptional mediators in the cross-talk between $\mathrm{P}$ and DA-initiated pathways in the facilitation of female sexual receptive behavior (Mani et al., 1994a,b,c, 1996). Studies from our laboratory also demonstrated that the DA-initiated second messenger signaling cascade involves the activation of PKA and neuronal phosphoprotein, dopamine and $3^{\prime}-5^{\prime}$ cyclic adenosine monophosphate (cAMP)regulated phosphoprotein-32 (DARPP-32), leading to the alterations in the phosphorylation dynamics and activation of PRs and/or its coregulators in the hypothalamus (Mani et al., 1996, 2000, 2006; Mani, 2006). Interestingly, using PR-A and PR-B mutant mice Mani et al. (2006) demonstrated that both PR-A and PR-B isoforms are essential for the expression of the full complement of DA-facilitated female reproductive behavior.
Ligand-independent activation of PRs has also been observed in behaviorally relevant stimuli such as the vaginal-cervical stimulation (VCS; Auger et al., 1996, 1997). Administration of the progesterone antagonist RU38486 to estradiol-primed female rats blocked sexual receptive responses to mating stimuli by VCS or mounting by a male rat, suggesting that the somatosensory information provided by the either of the stimuli could be due to ligandindependent activation of PRs. Induction of the immediate early gene (IEG) "Fos" was reduced in PR-rich areas like the medial POA and ventromedial nucleus of the hypothalamus upon RU38486 treatment (Auger et al., 2000). Based on PR immunostaining studies, Auger et al. (2000) suggest that PRs could be activated differentially by progesterone-dependent or progesterone-independent mechanisms, possibly leading to different neuronal consequences.

While the precise mechanism of ligand-independent activation of PRs has remained elusive, several studies suggest the involvement of PR phosphorylation in this mechanism. PKA inhibitors inhibit PR activation, suggesting that PR-mediated transcription could be modulated by phosphorylation of PR or other proteins in the transcription complex (Denner et al., 1990a,b; Rowan et al., 2000a,b). Growth factor-initiated signaling pathways (EGF and heregulin) enhance phosphorylation of PRs on distinct amino acids (Hagan et al., 2011). Enhanced phosphorylation can result in rapid nuclear translocation of unliganded PRs and nuclear export of liganded PRs, suggesting that kinase signaling could regulate $\mathrm{PR}$ nuclear sequestration, by altering nucleo-cytoplasmic shuttling (Labriola et al., 2003; Qiu and Lange, 2003; Qiu et al., 2003). PR sequestration in the nucleus protects inactive and active PRs from degradation by the $26 \mathrm{~S}$ proteosome pathway (Qiu and Lange, 2003; Qiu et al., 2003). Activated calcium-dependent kinase 2 (Cdk2) mediates transcriptional activation of PR by phosphorylating Ser400 moiety in the PR in a ligand-independent manner (Pierson-Mullany and Lange, 2004). Furthermore, cAMPdependent activation of $\mathrm{PR}$ does not involve direct phosphorylation of PR, but involves phosphorylation of SRC-1, to bring about the functional cooperation of SRC-1 and CREB-binding protein (Bai and Weigel, 1995; Rowan et al., 2000a,b; Narayanan et al., 2005).

\section{INTEGRATION OF NON-CLASSICAL AND CLASSICAL MECHANISMS OF P ACTION}

Classical PRs are not kinases, nor do they possess other known features of signaling molecules, leading to the questions on how they can interact with signaling molecules in a P-dependent manner and how this interaction can trigger a signaling cascade. The answers perhaps lie not only in $\mathrm{mPR}$-mediated signaling, but also in the proline-rich PXXP motif located in the N-terminal domain of PRs. Studies have implicated c-sarcoma (Src) tyrosine kinase as a key molecule in mediating P-initiated rapid signaling (Thomas and Brugge, 1997). Unliganded and liganded classical PRs have been shown to participate in cytoplasmic or membraneassociated signaling complexes that activate Src/Ras/Raf/MAPK signaling pathway in mammalian cells by a direct interaction with the Src homology 3 (SH3) domain of Src tyrosine kinases through the PXXP motif. MAPK activation can lead to phosphorylation of $\mathrm{PRs}$ and/or transcriptional coactivators, which can activate transcription directly by binding to progesterone response elements. 
Mutation of the nuclear localization signal of PR, which forces $\mathrm{PR}$ to the cytoplasm, enables P-dependent activation of c-Src and MAPK confirming that cytoplasmic localization was essential for c-Src-mediated signaling cascade (Boonyaratanakornkit et al., 2001).

Progesterone actions appear to involve integration of rapid membrane and slower genomic actions of P. Rapid non-classical activation of cytoplasmic signaling pathways by $\mathrm{P}$ can alter both transcription-independent and transcription-dependent actions (Boonyaratanakornkit et al., 2001; Faivre et al., 2005; Proietti et al., 2005; Faivre and Lange, 2007; Hagan et al., 2011). Rapid signaling can enhance transcription of the classical PRs through activation of signaling cascades that ultimately phosphorylate classical PRs per se (Denner et al., 1990b) and/or the phosphorylation of the coactivators (Denner et al., 1990b; Font de Mora and Brown, 2000; Rowan et al., 2000a,b; Xu et al., 2000). Interactions between membrane-initiated P effects and intracellular classical PRs have been observed in the facilitation of sexual behavior in female hamsters (DeBold and Frye, 1994a,b) suggesting that both classical and non-classical mechanisms act in concert rather than independently. Studies on activation of PRs by growth factors (Zhang et al.,
1994; Etgen et al., 2006), neurotransmitters (Mani et al., 1994a,b, 1996, 2000; Chu et al., 1999) and peptide hormones (Chappell and Levine, 2000; Gonzalez-Flores et al., 2009) suggest that classical and non-classical mechanisms are not mutually exclusive and signals generated at the membranes enhance gene expression regulated by classical intracellular hormone receptors. Cytoplasmic second messenger systems have been shown to modulate gene expression via multiple transcription factors or transcription coactivators (Watters et al., 1997; Watters and Dorsa, 1998). In several regions of the rat brain lacking the classical PRs, $\mathrm{E}_{2}$ causes a rapid increase in $\mathrm{p}$-CREB with no concomitant increases in protein or mRNA levels (Gu et al., 1996; Zhou et al., 1996). P, on the other hand, appears to have a bimodal effect on the phosphorylation of $\mathrm{CREB}$, bringing about a rapid decrease followed by an increase $(\mathrm{Gu}$ et al., 1996). These rapid effects on CREB phosphorylation also appear to be nuclear receptor-mediated since anti-hormones to ER and PR block the hormonal effects on CREB phosphorylation suggesting a cross-talk between the distinct signaling pathways. $\mathrm{P}$ has been shown to induce transcription of IEGs containing CREsequences such as $c$-fos and c-jun (Meredith et al., 1997). These genes encode the transcription factors, Fos and Jun, that can form

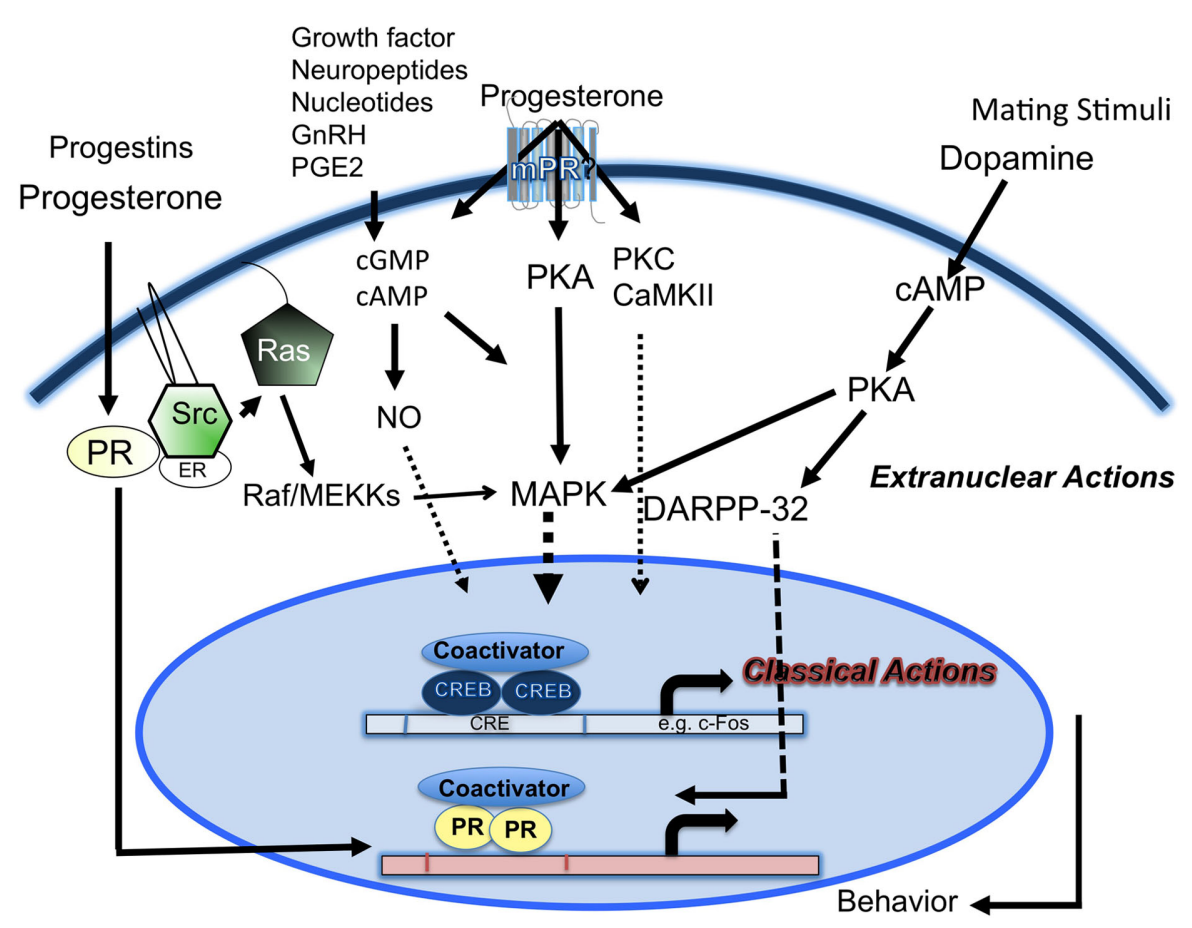

FIGURE 1 | A schematic representation of the cross-talk between extracellular and intracellular progesterone signaling pathways in female reproductive behavior. Classical mechanism of action by progesterone- and ring-A class of progestins, mediated by nuclear PRs, promotes interactions with coactivators, and plays a predominant role. Progesterone effects mediated by second messengers (CAMP, cGMP) and extranuclear signaling kinases (PKA, PKC, CaMKII), activates MAPK signal transduction cascade, phosphorylation of nuclear transcription factors (TFs), PRs/PR coactivators, and CREB. Progesterone and progestins, act via the Src kinase, interact with extranuclear PRs to activate MAPK cascade.

Progesterone acting via the extranuclear PKA/MAPK/DARPP-32 pathway can cause a decrease in phosphatase activity and an increase in phosphorylation of PR and/or its coactivators. Mating stimuli (VCS) and dopamine $D_{1}$ agonist can stimulate PKA activation. $D_{1}$ agonist-stimulated PKA-mediated pathway phosphorylates DARPP-32, which inhibits PP1, leading to the activation of CREB/PR/coactivators. VCS-stimulated PKA activation can also interact with MAPK cascade. Neuropeptides, nucleotides, $\mathrm{GnRH}$, and $\mathrm{PGE}_{2}$ can act through various receptor- and/or second messengers (cAMP, cGMP, NO) and transmit signals to the nuclear PRs or other TFs. Interactions between the signal transduction pathways may serve as an amplification mechanism to converge on nuclear TFs and/or coactivators to regulate gene transcription and translation to facilitate female reproductive behavior. 
hetero- or homodimers and regulate downstream gene expression by acting on target AP-1 DNA recognition sequences near promoter elements. In addition, recent studies have also indicated that nuclear receptor coregulators could also integrate steroid hormone signaling through CBP (Torchia et al., 1997; Mahajan and Samuels, 2000; Xu et al., 2000). Functional cooperation between MAPK cascade-mediated phosphorylation of coactivator SRC-1 and CBP has been demonstrated in the activation nuclear PRs in vitro (Rowan et al., 2000a).

\section{SUMMARY}

Integration of the extranuclear and intranuclear steroid signaling mechanisms PR activation is essential for neuroendocrine regulation of female reproductive behaviors. The interplay between the non-classical and classical pathways activated by $\mathrm{P}$ could be a "reinforcing" mechanism to achieve neuroendocrine integration required for complex behaviors like reproductive behaviors. The amplification process involving extranuclear signaling perhaps absolves the necessity for voluminous classic PR expression in the early stages of $\mathrm{P}$ action. A model depicting the interactions is given in Figure 1. Classical genomic pathway mediated by intracellular PRs, functioning as transcription factors, induces conformational changes, nuclear translocation, dimerization, and binding to PREs

\section{REFERENCES}

Apostolakis, E. M., Ramamurphy, M., Zhou, D., Onate, S., and O'Malley, B. W. (2002). Acute disruption of select steroid receptor coactivators prevents reproductive behavior in rats and unmasks genetic adaptation in knockout mice. Mol. Endocrinol. 16, 1511-1523.

Auger, A. P., LaRiccia, L. M., Moffatt, C. A., and Blaustein, J. D. (2000). Progesterone, but not progesteroneindependent activation of progestin receptors by a mating stimulus, rapidly decreases progestin receptor immunoreactivity in female rat brain. Horm. Behav. 37, 135-144.

Auger, A. P., Moffatt, C. A., and Blaustein, J. D. (1996). Reproductively-relevant stimuli induce Fos-immunoreactivity within progestin receptorcontaining neurons in localized regions of female rat forebrain. $J$. Neuroendocrinol. 8, 831-838.

Auger, A. P., Moffatt, C. A., and Blaustein, J. D. (1997). Progesteroneindependent activation of rat brain progestin receptors by reproductive stimuli. Endocrinology 138, 511-514.

Bai, W., and Weigel, N. L. (1995). Phosphorylation and steroid hormone action. Vitam. Horm. 51, 289-313.

Balasubramanian, B., Portillo, W., Reyna, A., Chen, J. Z., Moore, A. N., Dash, P. K., and Mani, S. K. (2008a). Nonclassical mechanisms of progesterone action in the brain: I. Protein kinase $\mathrm{C}$ activation in

in the promoters of target genes. Downstream cytoplasmic signaling cascades can mediate the non-classical mechanisms. Alternatively, a subpopulation of classic PRs localized in the cytoplasm can lead to the activation of the downstream kinase cascades. A biologic consequence of the cytoplasmic signaling cascades is to influence gene transcription.

Multiple intra- and intercellular signaling mechanisms share signaling components to ensure that the female is in behavioral estrus at the right time. While the functional role of multiple signaling pathways can be explained by their ability to relay, amplify, and integrate signals from a variety of extracellular stimuli, the molecular mechanisms by which this synchronization occurs remains unclear. It will be critical to understand how extranuclear signaling mechanisms regulate the equilibrium between transcriptionally active and inactive states of PRs and their coregulators, in regulating female reproductive behavior. Further insights into the mechanisms by which the multiple signals converge and reinforce, neuronal responses to environmental and behavioral events, to alter steroid hormone effects on female reproductive behavior.

\section{ACKNOWLEDGMENTS}

This work was supported by Public Health Service grant from National Institutes of Health HD 062512 (Shaila K. Mani).

by modulation of hypothalamic progestin receptors. Brain Res. 243, 287-300.

Blaustein, J. D. (1982b). Progesterone in high doses may overcome progesterone's desensitization effect on lordosis by translocation of hypothalamic progestin receptors. Horm. Behav. 16, 175-190.

Blaustein, J. D., and Feder, H. H. (1979a). Cytoplasmic progestin receptors in female guinea pig brain and their relationship to refractoriness in expression of female sexual behavior. Brain Res. 177, 489-498.

Blaustein, J. D., and Feder, H. H. (1979b). Cytoplasmic progestinreceptors in guinea pig brain: characteristics and relationship to the induction of sexual behavior. Brain Res. 169, 481-497.

Blaustein, J. D., and Feder, H. H. (1980). Nuclear progestin receptors in guinea pig brain measured by an in vitro exchange assay after hormonal treatments that affect lordosis. Endocrinology 106, 1061-1069.

Blaustein, J. D., and Mani, S. K. (2007). "Feminine sexual behavior from the neuroendocrine and molecular neurobiological perspectives," in Handbook of Neurochemistry and Molecular Neurobiology: Behavioral Neurochemistry, Neuroendocrinology and Molecular Neurobiology, ed. J. D. Blaustein and A. Lajtha (New York: Springer), 95-150.

Blaustein, J. D., and Olster, D. H. (1989). Gonadal Steroid Hormone
Receptors and Social Behaviors. Berlin: Springer-Verlag.

Blaustein, J. D., and Wade, G. N. (1977). Sequential inhibition of sexual behavior by progesterone in female rats: comparison with a synthetic antiestrogen. J. Comp. Physiol. Psychol. 91, 752-760.

Bloch, M., Schmidt, P. J., Danaceau, M., Murphy, J., Nieman, L., and Rubinow, D. R. (2000). Effects of gonadal steroids in women with a history of postpartum depression. Am. J. Psychiatry 157, 924-930.

Boonyaratanakornkit, V., Bi, Y., Rudd, M., and Edwards, D. P. (2008). The role and mechanism of progesterone receptor activation of extra-nuclear signaling pathways in regulating gene transcription and cell cycle progression. Steroids 73 , 922-928.

Boonyaratanakornkit, V., Scott, M. P., Ribon, V., Sherman, L., Anderson, S. M., Maller, J. L., Miller, W. T., and Edwards, D. P. (2001). Progesterone receptor contains a prolinerich motif that directly interacts with $\mathrm{SH} 3$ domains and activates c-Src family tyrosine kinases. Mol. Cell 8, 269-280.

Brown, T. J., Moore, M. J., and Blaustein, J. D. (1987). Maintenance of progesterone-facilitated sexual behavior in female rats requires continued hypothalamic protein synthesis and nuclear progestin receptor occupation. Endocrinology 121, 298-304. 
Carter, C. S., Landauer, M. R., Tierney, B. M., and Jones, T. (1976). Regulation of female sexual behavior in the golden hamster: behavioral effects of mating and ovarian hormones. J. Comp. Physiol. Psychol. 90, 839-850.

Chappell, P. E., and Levine, J. E. (2000). Stimulation of gonadotropinreleasing hormone surges by estrogen. I. Role of hypothalamic progesterone receptors. Endocrinology 141, 1477-1485.

Chu, H. P., and Etgen, A. M. (1997). A potential role of cyclic GMP in the regulation of lordosis behavior of female rats. Horm. Behav. 32, 125-132.

Chu, H. P., Morales, J. C., and Etgen, A. M. (1999). Cyclic GMP may potentiate lordosis behaviour by progesterone receptor activation. J. Neuroendocrinol. 11, 107-113.

Conneely, O. M., Kettelberger, D. M., Tsai, M. J., Schrader, W. T., and O’Malley, B. W. (1989). The chicken progesterone receptor $\mathrm{A}$ and $\mathrm{B}$ isoforms are products of an alternate translation initiation event. J. Biol. Chem. 264, 14062-14064.

DeBold, J. F., and Frye, C. A. (1994a). Genomic and non-genomic actions of progesterone in the control of female hamster sexual behavior. Horm. Behav. 28, 445-453.

DeBold, J. F., and Frye, C. A. (1994b). Progesterone and the neural mechanisms of hamster sexual behavior. Psychoneuroendocrinology 19, 563-579.

Dempsey, E. W., Hertz, R., and Young, W. C. (1936). The experimental induction of oestrus (sexual receptivity) in the normal and ovariectomized guinea pig. Am. J. Physiol. 116, 201-209.

Denner, L. A., Schrader, W. T., O’Malley, B. W., and Weigel, N. L. (1990a). Hormonal regulation and identification of chicken progesterone receptor phosphorylation sites. J. Biol. Chem. 265, 16548-16555.

Denner, L. A., Weigel, N. L., Maxwell, B. L., Schrader, W. T., and O'Malley, B. W. (1990b). Regulation of progesterone receptor-mediated transcription by phosphorylation. Science 250, 1740-1743.

Dreher, J. C., Schmidt, P. J., Kohn, P., Furman, D., Rubinow, D., and Berman, K. F. (2007). Menstrual cycle phase modulates rewardrelated neural function in women. Proc. Natl. Acad. Sci. U.S.A. 104, 2465-2470.

Etgen, A. M., Gonzalez-Flores, O., and Todd, B. J. (2006). The role of insulin-like growth factor-I and growth factor-associated signal transduction pathways in estradiol and progesterone facilitation of female reproductive behaviors. Front. Neuroendocrinol. 27, 363-375.

Fabre-Nys, C., and Gelez, H. (2007). Sexual behavior in ewes and other domestic ruminants. Horm. Behav. $52,18-25$.

Fadem, B. H., Barfield, R. J., and Whalen, R. E. (1979). Dose-response and time-response relationships between progesterone and the display of patterns of receptive and proceptive behavior in the female rat. Horm. Behav. 13, 40-48.

Faivre, E., Skildum, A., Pierson-Mullany, L., and Lange, C. A. (2005). Integration of progesterone receptor mediated rapid signaling and nuclear actions in breast cancer cell models: role of mitogen-activated protein kinases and cell cycle regulators. Steroids 70, 418-426.

Faivre, E. J., and Lange, C. A. (2007). Progesterone receptors upregulate Wnt-1 to induce epidermal growth factor receptor transactivation and c-Src-dependent sustained activation of Erk1/2 mitogen-activated protein kinase in breast cancer cells. Mol. Cell. Biol. 27, 466-480.

Falkenstein, E., Meyer, C., Eisen, C., Scriba, P. C., and Wehling, M. (1996). Full-length cDNA sequence of a progesterone membranebinding protein from porcine vascular smooth muscle cells. Biochem. Biophys. Res. Commun. 229, 86-89.

Falkenstein, E., Schmieding, K., Lange, A., Meyer, C., Gerdes, D., Welsch, U., and Wehling, M. (1998). Localization of a putative progesterone membrane binding protein in porcine hepatocytes. Cell. Mol. Biol. (Noisy-le-grand) 44, 571-578.

Feder, H. H. (1984). Hormones and sexual behavior. Annu. Rev. Psychol. 35, 165-200.

Ferrell, J. E. Jr. (1999). Xenopus oocyte maturation: new lessons from a good egg. Bioessays 21, 833-842.

Ferrell, J. E. Jr., and Machleder, E. M. (1998). The biochemical basis of an all-or-none cell fate switch in Xenopus oocytes. Science 280, 895-898.

Flood, J. F., Morley, J. E., and Roberts, E. (1992). Memory-enhancing effects in male mice of pregnenolone and steroids metabolically derived from it. Proc. Natl. Acad. Sci. U.S.A. 89, 1567-1571.

Font de Mora, J., and Brown, M. (2000). AIB1 is a conduit for kinasemediated growth factor signaling to the estrogen receptor. Mol. Cell. Biol. 20, 5041-5047.
Fraile, I. G., McEwen, B. S., and Pfaff, D. W. (1987). Progesterone inhibition of aggressive behaviors in hamsters. Physiol. Behav. 39, 225-229.

Gerdes, D., Wehling, M., Leube, B., and Falkenstein, E. (1998). Cloning and tissue expression of two putative steroid membrane receptors. Biol. Chem. 379, 907-911.

Gomez-Camarillo, M. A., Beyer, C. Lucio, R. A., Garcia-Juarez, M., Gonzalez-Arenas, A., CamachoArroyo, I., Komisaruk, B. R., and Gonzalez-Flores, O. (2011). Differential effects of progesterone and genital stimulation on sequential inhibition of estrous behavior and progesterone receptor expression in the rat brain. Brain Res. Bull. 85 , 201-206.

Gonzalez-Flores, O., Etgen, A. M. Komisaruk, B. K., Gomora-Arrati, P., Macias-Jimenez, A., LimaHernandez, F. J., Garcia-Juarez, M., and Beyer, C. (2008). Antagonists of the protein kinase A and mitogenactivated protein kinase systems and of the progestin receptor block the ability of vaginocervical/flankperineal stimulation to induce female rat sexual behaviour. $J$. Neuroendocrinol. 20, 1361-1367.

Gonzalez-Flores, O., Gomora-Arrati, P., Garcia-Juarez, M., GomezCamarillo, M. A., Lima-Hernandez, F. J., Beyer, C., and Etgen, A. M. (2009). Nitric oxide and ERK/MAPK mediation of estrous behavior induced by GnRH, PGE2 and db-cAMP in rats. Physiol. Behav. 96, 606-612.

Gonzalez-Flores, O., Ramirez-Orduna, J. M., Lima-Hernandez, F. J., GarciaJuarez, M., and Beyer, C. (2006). Differential effect of kinase A and C blockers on lordosis facilitation by progesterone and its metabolites in ovariectomized estrogen-primed rats. Horm. Behav. 49, 398-404.

Gonzalez-Flores, O., Shu, J., CamachoArroyo, I., and Etgen, A. M. (2004). Regulation of lordosis by cyclic 3'5'-guanosine monophosphate, progesterone, and its 5alphareduced metabolites involves mitogen-activated protein kinase. Endocrinology 145, 5560-5567.

Goy, R. W., Phoenix, C. H., and Young, W. C. (1966). Inhibitory action in the corpus luteum on the hormonal induction of estrous behavior in the guinea pig. Gen. Comp. Endocrinol. 6, 267-275.

Gu, G., Rojo, A. A., Zee, M. C., Yu, J., and Simerly, R. B. (1996). Hormonal regulation of CREB phosphorylation in the anteroventral periventricular nucleus. J. Neurosci. 16, 3035-3044.
Guerra-Araiza, C., Gomora-Arrati, P., Garcia-Juarez, M., ArmengualVillegas, A., Miranda-Martinez, A., Lima-Hernandez, F. J., CamachoArroyo, I., and Gonzalez-Flores, O. (2009). Role of progesterone receptor isoforms in female sexual behavior induced by progestins in rats. Neuroendocrinology 90, 73-81.

Hagan, C. R., Daniel, A. R., Dressing, G. E., and Lange, C. A. (2011). Role of phosphorylation in progesterone receptor signaling and specificity. Mol. Cell. Endocrinol. PMID: 21945472. [Epub ahead of print].

Havens, M. D., and Rose, J. D. (1988). Estrogen-dependent and estrogenindependent effects of progesterone on the electrophysiological excitability of dorsal midbrain neurons in golden hamsters. Neuroendocrinology 48, 120-129.

Horwitz, K. B., Tung, L., and Takimoto, G. S. (1996). Novel mechanisms of antiprogestin action. Acta Oncol. 35, 129-140.

Karteris, E., Zervou, S., Pang, Y., Dong, J., Hillhouse, E. W., Randeva, H. S., and Thomas, P. (2006). Progesterone signaling in human myometrium through two novel membrane G protein-coupled receptors: potential role in functional progesterone withdrawal at term. Mol. Endocrinol. 20, 1519-1534.

Kastner, P., Bocquel, M. T., Turcotte, B., Garnier, J. M., Horwitz, K. B., Chambon, P., and Gronemeyer, H. (1990). Transient expression of human and chicken progesterone receptors does not support alternative translational initiation from a single mRNA as the mechanism generating two receptor isoforms. J. Biol. Chem. 265, 12163-12167.

Katzenellenbogen, J. A., O’Malley, B. W., and Katzenellenbogen, B. S. (1996). Tripartite steroid hormone receptor pharmacology: interaction with multiple effector sites as a basis for the cell- and promoterspecific action of these hormones. Mol. Endocrinol. 10, 119-131.

Kelly, M. J., Moss, R. L., and Dudley, C. A. (1977a). The effects of microelectrophoretically applied estrogen, cortisol and acetylcholine on medial preoptic-septal unit activity throughout the estrous cycle of the female rat. Exp. Brain Res. 30, 53-64. Kelly, M. J., Moss, R. L., Dudley, C. A., and Fawcett, C. P. (1977b). The specificity of the response of preoptic-septal area neurons to estrogen: 17alpha-estradiol versus 17beta-estradiol and the response of extrahypothalamic neurons. Exp. Brain Res. 30, 43-52. 
Kow, L. M., Mobbs, C. V., and Pfaff, D. W. (1994). Roles of secondmessenger systems and neuronal activity in the regulation of lordosis by neurotransmitters, neuropeptides, and estrogen: a review. Neurosci. Biobehav. Rev. 18, 251-268.

Kraus, W. L., Montano, M. M., and Katzenellenbogen, B. S. (1993). Cloning of the rat progesterone receptor gene 5'-region and identification of two functionally distinct promoters. Mol. Endocrinol. 7, 1603-1616.

Krebs, C. J., Jarvis, E. D., Chan, J., Lydon, J. P., Ogawa, S., and Pfaff, D. W. (2000). A membrane-associated progesterone-binding protein, $25-\mathrm{Dx}$, is regulated by progesterone in brain regions involved in female reproductive behaviors. Proc. Natl. Acad. Sci. U.S.A. 97, 12816-12821.

Labriola, L., Salatino, M., Proietti, C. J., Pecci, A., Coso, O. A., Kornblihtt, A. R., Charreau, E. H., and Elizalde, P. V. (2003). Heregulin induces transcriptional activation of the progesterone receptor by a mechanism that requires functional ErbB-2 and mitogen-activated protein kinase activation in breast cancer cells. Mol. Cell. Biol. 23, 1095-1111.

Leonhardt, S. A., Boonyaratanakornkit, V., and Edwards, D. P. (2003). Progesterone receptor transcription and non-transcription signaling mechanisms. Steroids 68, 761-770.

Lutz, L. B., Kim, B., Jahani, D., and Hammes, S. R. (2000). G protein beta gamma subunits inhibit nongenomic progesterone-induced signaling and maturation in Xenopus laevis oocytes. Evidence for a release of inhibition mechanism for cell cycle progression. J. Biol. Chem. 275, 41512-41520.

Mahajan, M. A., and Samuels, H. H. (2000). A new family of nuclear receptor coregulators that integrate nuclear receptor signaling through CREB-binding protein. Mol. Cell. Biol. 20, 5048-5063.

Mani, S. (2008). Progestin receptor subtypes in the brain: the known and the unknown. Endocrinology 149, 2750-2756.

Mani, S., and Portillo, W. (2010). Activation of progestin receptors in female reproductive behavior: interactions with neurotransmitters. Front. Neuroendocrinol.31, 157-171.

Mani, S. K. (2006). Signaling mechanisms in progesteroneneurotransmitter interactions. Neuroscience 138, 773-781.

Mani, S. K., Allen, J. M., Clark, J. H., Blaustein, J. D., and O'Malley,
B. W. (1994a). Convergent pathways for steroid hormone- and neurotransmitter-induced rat sexual behavior. Science 265, 1246-1249.

Mani, S. K., Allen, J. M., Rettori, V., McCann, S. M., O’Malley, B. W., and Clark, J. H. (1994b). Nitric oxide mediates sexual behavior in female rats. Proc. Natl. Acad. Sci. U.S.A. 91, 6468-6472.

Mani, S. K., Blaustein, J. D., Allen, J. M., Law, S. W., O’Malley, B. W. and Clark, J. H. (1994c). Inhibition of rat sexual behavior by antisense oligonucleotides to the progesterone receptor. Endocrinology 135, 1409-1414.

Mani, S. K., Allen, J. M., Lydon, J. P., Mulac-Jericevic, B., Blaustein, J. D., DeMayo, F. J., Conneely, O., and O’Malley, B. W. (1996). Dopamine requires the unoccupied progesterone receptor to induce sexual behavior in mice. Mol. Endocrinol. 10, 1728-1737.

Mani, S. K., Fienberg, A. A., O'Callaghan, J. P., Snyder, G. L., Allen, P. B., Dash, P. K., Moore, A. N., Mitchell, A. J., Bibb, J., Greengard, P., and O'Malley, B. W. (2000). Requirement for DARPP-32 in progesterone-facilitated sexual receptivity in female rats and mice. Science 287, 1053-1056.

Mani, S. K., and O'Malley, B. W. (2002). "Molecular mechanisms of progesterone receptor action," in Hormones, Brain and Behavior, eds A. M. Etgen, D. W. Pfaff, S. E. Fahrbach, and R. T. Rubin (San Diego: Academic Press), 643-682.

Mani, S. K., Reyna, A. M., Chen, J. Z., Mulac-Jericevic, B., and Conneely, O. M. (2006). Differential response of progesterone receptor isoforms in hormone-dependent and -independent facilitation of female sexual receptivity. Mol. Endocrinol. 20, 1322-1332.

McKenna, N. J., Lanz, R. B., and O’Malley, B. W. (1999). Nuclear receptor coregulators: cellular and molecular biology. Endocr. Rev. 20, 321-344.

Meiri, H. (1986). Is synaptic transmission modulated by progesterone? Brain Res. 385, 193-196.

Meisel, R. L., Fraile, I. G., and Pfaff, D. W. (1990). Hypothalamic sites of progestin action on aggression and sexual behavior in female Syrian hamsters. Physiol. Behav. 47, 219-223.

Meisel, R. L., and Pfaff, D. W. (1984). RNA and protein synthesis inhibitors: effects on sexual behavior in female rats. Brain Res. Bull. 12, 187-193.
Meisel, R. L., and Pfaff, D. W. (1985). Specificity and neural sites of action of anisomycin in the reduction or facilitation of female sexual behavior in rats. Horm. Behav. 19 237-251.

Meredith, J. M., Auger, A. P., and Blaustein, J. D. (1997). D1 dopamine receptor agonist (SKF-38393) induction of Fos immunoreactivity in progestin receptor-containing areas of female rat brain. $J$. Neuroendocrinol. 9, 385-394.

Meyer, C., Schmid, R., Scriba, P. C., and Wehling, M. (1996). Purification and partial sequencing of highaffinity progesterone-binding site(s) from porcine liver membranes. Eur. J. Biochem. 239, 726-731.

Migliaccio, A., Piccolo, D., Castoria, G., Di Domenico, M., Bilancio, A., Lombardi, M., Gong, W., Beato, M., and Auricchio, F. (1998). Activation of the Src/p21ras/Erk pathway by progesterone receptor via cross-talk with estrogen receptor. $E M B O J .17$, 2008-2018.

Molenda, H. A., Griffin, A. L., Auger A. P., McCarthy, M. M., and Tetel, M. J. (2002). Nuclear receptor coactivators modulate hormonedependent gene expression in brain and female reproductive behavior in rats. Endocrinology 143, 436-444.

Molenda-Figueira, H. A., Murphy, S. D., Shea, K. L., Siegal, N. K., Zhao, Y., Chadwick, J. G. Jr., Denner, L. A., and Tetel, M. J. (2008). Steroid receptor coactivator-1 from brain physically interacts differentially with steroid receptor subtypes. Endocrinology 149, 5272-5279.

Molenda-Figueira, H. A., Williams, C. A., Griffin, A. L., Rutledge, E. M., Blaustein, J. D., and Tetel, M. J. (2006). Nuclear receptor coactivators function in estrogen receptorand progestin receptor-dependent aspects of sexual behavior in female rats. Horm. Behav. 50, 383-392.

Morin, L. P. (1977). Theoretical review. Progesterone: inhibition of rodent sexual behavior. Physiol. Behav. 18, 701-715.

Narayanan, R., Adigun, A. A., Edwards, D. P., and Weigel, N. L. (2005). Cyclin-dependent kinase activity is required for progesterone receptor function: novel role for cyclin $\mathrm{A} / \mathrm{Cdk} 2$ as a progesterone receptor coactivator. Mol. Cell. Biol. 25, 264-277.

Numan, M., Roach, J. K., del Cerro, M. C., Guillamon, A., Segovia, S., Sheehan, T. P., and Numan, M. J. (1999). Expression of intracellular progesterone receptors in rat brain during different reproductive states, and involvement in maternal behavior. Brain Res. 830 , 358-371.

Ogawa, H., Nishi, M., and Kawata, M. (2001). Localization of nuclear coactivators p300 and steroid receptor coactivator 1 in the rat hippocampus. Brain Res. 890, 197-202.

Ogawa, S., Olazabal, U. E., Parhar, I. S., and Pfaff, D. W. (1994). Effects of intrahypothalamic administration of antisense DNA for progesterone receptor mRNA on reproductive behavior and progesterone receptor immunoreactivity in female rat. $J$. Neurosci. 14, 1766-1774.

O’Malley, B. W., Schrader, W. T., Mani, S., Smith, C., Weigel, N. L., Conneely, O. M., and Clark, J. H. (1995). An alternative ligand-independent pathway for activation of steroid receptors. Recent Prog. Horm. Res. 50, 333-347.

Parsons, B., MacLusky, N. J., Krey, L., Pfaff, D. W., and McEwen, B. S. (1980). The temporal relationship between estrogen-inducible progestin receptors in the female rat brain and the time course of estrogen activation of mating behavior. Endocrinology 107, 774-779.

Petitti, N., and Etgen, A. M. (1989). Progesterone depression of norepinephrine-stimulated cAMP accumulation in hypothalamic slices. Brain Res. Mol. Brain Res. 5, 109-119.

Petitti, N., and Etgen, A. M. (1990). Alpha 1-adrenoceptor augmentation of beta-stimulated cAMP formation is enhanced by estrogen and reduced by progesterone in rat hypothalamic slices. J. Neurosci. 10, 2842-2849.

Pfaff, D. W. (1980). Estrogens and Brain Functions. New York: Springer-Verlag.

Pfaff, D. W., Ogawa, S., Kia, K., Vasudevan, N., Krebs, C., Frohlich, J., and Kow, L. M. (2002). "Genetic mechanisms in neural and hormonal controls over female reproductive behaviors," in Hormones, Brain and Behavior, eds D. W. Pfaff, A. P. Arnold, A. M. Etgen, S. E. Fahrbach, and R. T. Rubin (San Diego: Academic Press) 441-510.

Pfaff, D. W., Schwartz-Giblin, S., McCarthy, M. M., and Kow, L. M. (1994). Cellular and Molecular Mechanisms of Female Reproductive Behavior. New York: Raven Press.

Pierson-Mullany, L. K., and Lange, C. A. (2004). Phosphorylation of progesterone receptor serine 400 mediates ligand-independent transcriptional activity in response to activation of 
cyclin-dependent protein kinase 2. Mol. Cell. Biol. 24, 10542-10557.

Pollio, G., Xue, P., Zanisi, M., Nicolin, A., and Maggi, A. (1993). Antisense oligonucleotide blocks progesterone-induced lordosis behavior in ovariectomized rats. Brain Res. Mol. Brain Res. 19, 135-139.

Proietti, C., Salatino, M., Rosemblit, C., Carnevale, R., Pecci, A., Kornblihtt, A. R., Molinolo, A. A., Frahm, I., Charreau, E. H., Schillaci, R., and Elizalde, P. V. (2005). Progestins induce transcriptional activation of signal transducer and activator of transcription 3 (Stat3) via a Jakand Src-dependent mechanism in breast cancer cells. Mol. Cell. Biol. 25, 4826-4840.

Qiu, M., and Lange, C. A. (2003). MAP kinases couple multiple functions of human progesterone receptors: degradation, transcriptional synergy, and nuclear association. J. Steroid Biochem. Mol. Biol. 85, 147-157.

Qiu, M., Olsen, A., Faivre, E., Horwitz, K. B., and Lange, C. A. (2003). Mitogen-activated protein kinase regulates nuclear association of human progesterone receptors. $\mathrm{Mol}$. Endocrinol. 17, 628-642.

Rainbow, T. C., McGinnis, M. Y., Davis, P. G., and McEwen, B. S. (1982). Application of anisomycin to the lateral ventromedial nucleus of the hypothalamus inhibits the activation of sexual behavior by estradiol and progesterone. Brain Res. 233, 417-423.

Ramirez, V. D., Dluzen, D. E., and Ke, F. C. (1990). Effects of progesterone and its metabolites on neuronal membranes. Ciba Found. Symp. 153, 125-141; discussion 141-124.

Rowan, B. G., Garrison, N., Weigel, N. L., and O'Malley, B. W. (2000a). 8-Bromo-cyclic AMP induces phosphorylation of two sites in SRC-1 that facilitate ligand-independent activation of the chicken progesterone receptor and are critical for functional cooperation between SRC-1 and CREB binding protein. Mol. Cell. Biol. 20, 8720-8730.

Rowan, B. G., Weigel, N. L., and O’Malley, B. W. (2000b). Phosphorylation of steroid receptor coactivator-1. Identification of the phosphorylation sites and phosphorylation through the mitogenactivated protein kinase pathway. $J$. Biol. Chem. 275, 4475-4483.

Rubin, B. S., and Barfield, R. J. (1983). Induction of estrous behavior in ovariectomized rats by sequential replacement of estrogen and progesterone to the ventromedial hypothalamus. Neuroendocrinology 37, 218-224.

Schumacher, M., Coirini, H., Pfaff, D. W., and McEwen, B. S. (1990). Behavioral effects of progesterone associated with rapid modulation of oxytocin receptors. Science 250, 691-694.

Schumacher, M., Coirini, H., Robert, F., Guennoun, R., and El-Etr, M. (1999). Genomic and membrane actions of progesterone: implications for reproductive physiology and behavior. Behav. Brain Res. 105, 37-52.

Selmin, O., Lucier, G. W., Clark, G. C., Tritscher, A. M., Vanden Heuvel, J. P., Gastel, J. A., Walker, N. J., Sutter, T. R., and Bell, D. A. (1996). Isolation and characterization of a novel gene induced by 2,3,7,8-tetrachlorodibenzo-pdioxin in rat liver. Carcinogenesis 17 , 2609-2615.

Sleiter, N., Pang, Y., Park, C., Horton, T. H., Dong, J., Thomas, P., and Levine, J. E. (2009). Progesterone receptor A (PRA) and PRB-independent effects of progesterone on gonadotropinreleasing hormone release. Endocrinology 150, 3833-3844.

Smith, S. S., Waterhouse, B. D., and Woodward, D. J. (1987). Sex steroid effects on extrahypothalamic CNS. II. Progesterone, alone and in combination with estrogen, modulates cerebellar responses to amino acid neurotransmitters. Brain Res. 422, 52-62.

Sodersten, P., and Eneroth, P. (1981). Evidence that progesterone does not inhibit the induction of sexual receptivity by oestradiol-17 beta in the rat. J. Endocrinol. 89, 63-69.

Sodersten, P., and Hansen, S. (1977). Effects of oestradiol and progesterone on the induction and duration of sexual receptivity in cyclic female rats. J. Endocrinol. 74, 477-485.

Sodersten, P., and Hansen, S. (1979). Induction of sexual receptivity by oestradiol benzoate in cyclic female rats: influence of ovarian secretions before injection of oestradiol benzoate. J. Endocrinol. 80, 389-395.

Thomas, P., Pang, Y., Dong, J., Groenen, P., Kelder, J., de Vlieg, J., Zhu, Y., and Tubbs, C. (2007). Steroid and $\mathrm{G}$ protein binding characteristics of the seatrout and human progestin membrane receptor alpha subtypes and their evolutionary origins. Endocrinology 148, 705-718.
Thomas, S. M., and Brugge, J. S. (1997). Cellular functions regulated by Src family kinases. Annu. Rev. Cell Dev. Biol. 13, 513-609.

Torchia, J., Rose, D. W., Inostroza, J. Kamei, Y., Westin, S., Glass, C. K., and Rosenfeld, M. G. (1997). The transcriptional co-activator $\mathrm{p} / \mathrm{CIP}$ binds CBP and mediates nuclear-receptor function. Nature 387, 677-684.

Tsai, M. J., and O'Malley, B. W. (1994). Molecular mechanisms of action of steroid/thyroid receptor superfamily members. Annu. Rev. Biochem. 63 451-486.

Tubbs, C., and Thomas, P. (2008). Functional characteristics of membrane progestin receptor alpha (mPRalpha) subtypes: a review with new data showing mPRalpha expression in seatrout sperm and its association with sperm motility. Steroids 73, 935-941.

Vallee, M., Mayo, W., Darnaudery, M. Corpechot, C., Young, J., Koehl, M., Le Moal, M., Baulieu, E. E., Robel, P., and Simon, H. (1997). Neurosteroids: deficient cognitive performance in aged rats depends on low pregnenolone sulfate levels in the hippocampus. Proc. Natl. Acad. Sci. U.S.A. 94, 14865-14870.

Wagner, C. K. (2006). The many faces of progesterone: a role in adult and developing male brain. Front. Neuroendocrinol. 27, 340-359.

Wagner, C. K., Nakayama, A. Y., and De Vries, G. J. (1998). Potential role of maternal progesterone in the sexual differentiation of the brain. Endocrinology 139, 3658-3661.

Watters, J. J., Campbell, J. S., Cunningham, M. J., Krebs, E. G., and Dorsa, D. M. (1997). Rapid membrane effects of steroids in neuroblastoma cells: effects of estrogen on mitogen activated protein kinase signalling cascade and c-fos immediate early gene transcription. Endocrinology 138, 4030-4033.

Watters, J. J., and Dorsa, D. M. (1998). Transcriptional effects of estrogen on neuronal neurotensin gene expression involve cAMP/protein kinase A-dependent signaling mechanisms. J. Neurosci. 18, 6672-6680.

Whalen, R. E. (1974). Estrogenprogesterone induction of mating in female rats. Horm. Behav. 5, 157-162.

Xu, Y., Klein-Hitpass, L., and Bagchi, M. K. (2000). E1A-mediated repression of progesterone receptor-dependent transactivation involves inhibition of the assembly of a multisubunit coactivation complex. Mol. Cell. Biol. 20, 2138-2146.
Yore, M. A., Im, D., Webb, L. K., Zhao, Y., Chadwick, J. G. Jr., MolendaFigueira, H. A., Haidacher, S. J., Denner, L., and Tetel, M. J. (2010). Steroid receptor coactivator-2 expression in brain and physical associations with steroid receptors. Neuroscience 169, 1017-1028.

Young, W. C. (1969). "Psychobiology of sexual behavior in the guinea pig," in Advances in the Study of Behavior, eds R. A. Hinde, D. S. Lehrman, and E. Shaw (New York: Academic Press), 1-110.

Zhang, Y., Bai, W., Allgood, V. E., and Weigel, N. L. (1994). Multiple signaling pathways activate the chicken progesterone receptor. $\mathrm{Mol}$. Endocrinol. 8, 577-584.

Zhou, Y., Watters, J. J., and Dorsa, D. M. (1996). Estrogen rapidly induces the phosphorylation of the cAMP response element binding protein in rat brain. Endocrinology 137, 2163-2166.

Zhu, Y., Bond, J., and Thomas, P. (2003a). Identification, classification, and partial characterization of genes in humans and other vertebrates homologous to a fish membrane progestin receptor. Proc. Natl. Acad. Sci. U.S.A. 100, 2237-2242.

Zhu, Y., Rice, C. D., Pang, Y., Pace, M. and Thomas, P. (2003b). Cloning, expression, and characterization of a membrane progestin receptor and evidence it is an intermediary in meiotic maturation of fish oocytes. Proc. Natl. Acad. Sci. U.S.A. 100, 2231-2236.

Conflict of Interest Statement: The authors declare that the research was conducted in the absence of any commercial or financial relationships that could be construed as a potential conflict of interest.

Received: 10 December 2011; paper pending published: 26 December 2011; accepted: 10 January 2012; published online: 30 January 2012.

Citation: Mani SK and Oyola MG (2012) Progesterone signaling mechanisms in brain and behavior. Front. Endocrin. 3:7. doi: 10.3389/fendo.2012.00007

This article was submitted to Frontiers in Neuroendocrine Science, a specialty of Frontiers in Endocrinology.

Copyright (c) 2012 Mani and Oyola. This is an open-access article distributed under the terms of the Creative Commons Attribution Non Commercial License, which permits non-commercial use, distribution, and reproduction in other forums, provided the original authors and source are credited. 